\title{
. The Ontogeny of Thymidine Kinase in Tissues of Man and Rat
}

\author{
ANNEMARIE HERZFELD, ${ }^{(42)}$ SUZANNE M. RAPER, AND IRA GORE ${ }^{(43)}$ \\ Cancer Research Institute, New England Deaconess Hospital, Boston, Massachusetts, USA
}

\begin{abstract}
Summary
Thymidine kinase activities, virtually all soluble in rat lung, liver, and small intestine, descreased abruptly late in gestation or immediately after birth. An injection of thyroxine delayed the fetal but not the neonatal changes in liver activity. An injection of cortisol decreased hepatic and pulmonary thymidine kinase activities in both fetal and neonatal rats but had little effect on the intestinal enzyme. Premature extrauterinization led to an earlier occurrence of the quantitative changes in thymidine kinase activity usually seen at term. Birth-associated changes included a rapid transitory increase in the hepatic enzyme and the virtual loss of intestinal thymidine kinase activity.

In human tissues, the soluble thymidine kinase in liver remained high between the 11th and 22nd wk of gestation whereas the particulate enzyme, the predominant form in adult liver, rose in the second half of gestation and reached adult levels at birth. In human lung, the soluble enzyme started to decrease by the 16th gestational wk, whereas the particulate thymidine kinase reached the higher adult levels late in gestation. Thymidine kinase in adult human tissues was predominantly particulate.
\end{abstract}

\section{Speculation}

The postnatal accumulation of soluble thymidine kinase in rat liver, lung, and small intestine may be associated with new DNA synthesis preliminary to the emergence of ontogenically "new" enzyme clusters at discrete intervals after birth. The regulatory role of thyroxine and cortisol on thymidine kinase in liver and lung may also be related to the effects of those hormones on other hepatic and pulmonary enzymes. The appearance of particulate thymidine kinase in human tissues relatively late in development suggests that its physiological function differs from that of the soluble form. Its predominance in adult human liver, lung, and colon and its virtual absence from adult rat tissues indicate a phylogenic as well as an ontogenic significance of this alternate form of the enzyme.

The role of the salvage pathway for DNA synthesis can be assessed by the potential for the phosphorylation of thymidine by thymidine kinase (EC 2.7.1.75), the putative "limiting" enzyme in the pathway. Previous studies $(6,13,30)$ have reported that the activity of this enzyme in fetal and neoplastic rat tissues exceeds those in most normal adult tissues and that a precipitous decrease in hepatic thymidine kinase is observed shortly before birth (30). The late fetal drop in liver thymidine kinase could be enhanced prematurely by injecting fetuses (16 to 20 days gestation) with cortisol (11); declines in lung thymidine kinase concentrations after cortisol injection have also been reported (7). Both the normal and the cortisol-induced decreases in enzyme activity were accompanied by reductions in the hematopoietic elements of fetal rat liver, suggesting that thymidine kinase in the fetal liver might be associated with the hematopoietic rather than the parenchymal cell population (30). This hypothesis is supported by the relatively high levels of the enzyme in tissues that not only proliferate rapidly in the adult but also have hematopoietic potential, e.g., spleen, thymus, and bone marrow $(10,33)$. The implication of these observations prompted us to explore the developmental changes in the thymidine kinase activities in rat liver after the time when that organ has ceased to contribute significantly to hematopoiesis and to determine if the normal postnatal decreases in thymidine kinase are as abrupt in rat tissues that do not have hematopoietic potential (e.g., small intestine and lung). We also investigated the effects of the process of birth per se (normal or premature delivery) on the activities of this enzyme during the first postnatal day and compared the effects of a cortisol or thyroxine injection on the enzyme in liver, lung, and small intestine before and after birth. To test whether the developmental changes in the thymidine kinase activities in rat tissues provide a model for maturational events in this enzyme in human tissues, we also measured the thymidine kinase in livers and lungs of electively aborted fetuses and from autopsy (neonates) and surgical biopsy specimens of adult humans. The major portion of thymidine kinase in the rat was restricted to the soluble fraction of tissues $(21,33)$. It has previously been shown that much of the enzyme in adult human tissues is associated with particles (especially mitochondria) $(21,26,36)$ and that the properties of the cytosolic and particulate form of the enzyme differ $(23,26,32,34$, 36 ). We compared the developmental changes in the amounts of the soluble and particle-bound thymidine kinase in human liver, intestine, and lung. Our results demonstrate that their developmental histories are quite dissimilar.

\section{MATERIALS AND METHODS}

Tissues from dead human fetuses (between the 10th and 22nd wk of gestation) aborted by prostaglandin or hysterotomy or, in the two oldest fetuses, spontaneously, were obtained through the courtesy of Dr. Shirley Driscoll, Boston Hospital for Women, Boston, MA. Enzyme activities in tissues of fetuses aborted by hysterotomy or prostaglandin were not affected by the method of abortion (21). Autopsy samples from infants $3 \mathrm{hr}$ to 6 days old were received through the cooperation of $\mathrm{Dr}$. W. Taeusch, Boston Hospital for Women. Human adult samples were portions of resected tissues taken for diagnostic purposes during surgery and made available to us through the courtesy of Dr. M. A. Legg, Department of Pathology, New England Deaconess Hospital, Boston, MA. Autopsy and surgical specimens were obtained $1 / 4$ to $4 \mathrm{hr}$ after resection or death. Adult (60 to 90 days) male rats were albinos of the Kx (New England Deaconess Hospital breeding colony) or CDF strains (Charles River breeding colony, Wilmington, MA). Fetal rats were progeny of time-mated $\mathrm{Kx}$ or $\mathrm{CDF}$ dams. Fetal ages of rats were estimated from the correlation between body weight and age according to Knox and Rosenoer (25).

Thyroxine ( $3 \mu \mathrm{g}$ per fetus) or cortisol $(0.125 \mathrm{mg}$ per fetus hydrocortisone acetate; Merck, Sharp, and Dohme, Nutley, NJ) in 0.05 to $0.1 \mathrm{ml} 0.9 \% \mathrm{NaCl}$ solution was injected into rat fetuses in one uterine horn of a laparotomized dam $18 \mathrm{hr}$ before assay. Postnatal rats were injected IP with $20 \mu \mathrm{g}$ thyroxine or $0.25 \mathrm{mg}$ 
cortisol per $10 \mathrm{~g}$ body weight $18 \mathrm{hr}$ before assay. Untreated littermates served as controls.

Tissue preparations, begun immediately after receipt of the human tissue or excision of rat organs, were identical for human and rat tissues. Small intestines of rats, washed with $0.9 \% \mathrm{NaCl}$ solution before homogenization, were used in their entirety (fetals); in rats between birth and 10 days, the upper halves of intestines were homogenized whereas only jejunum $(5$ to $7 \mathrm{~cm}$ below the ligament of Treitz) was used in older animals. Colon consisted of the 5 to $7 \mathrm{~cm}$ immediately below the caecum. Minced tissues, kept at $0^{\circ} \mathrm{C}$ throughout, were disrupted in 9 volumes cold $0.15 \mathrm{M} \mathrm{KCl}$ in glass-Teflon homogenizers and centrifuged for 30 min at $100,000 \times g$ to obtain soluble and particulate fractions. The pellets were resuspended to the original volume in a final concentration of $0.5 \%$ Triton X-100 (16) (Sigma Biochemical Co., St. Louis, MO) in water and kept at $0^{\circ} \mathrm{C}$ for $30 \mathrm{~min}$ before assay. All enzyme activities were determined in freshly prepared samples because thymidine kinase was sometimes unstable in cytosol or particles when stored overnight at +4 or $-20^{\circ} \mathrm{C}$. The activity was no higher when assayed in the tissue homogenized in $0.15 \mathrm{M} \mathrm{KCl}$, $\mathrm{pH} 7.4$, containing either 1 to $5 \mathrm{mM} \mathrm{ATP}$ or 0.5 to $1.0 \mathrm{mM}$ thymidine. To determine the subcellular distribution of thymidine kinase in neonatal and adult liver and spleen, portions of tissues were homogenized in $0.25 \mathrm{M}$ sucrose and centrifuged as described in the legend to Table 1 . Nuclei and mitochondria from adult liver were separated by overlaying two volumes of $0.5 \mathrm{M}$ sucrose with one volume of homogenate in $0.25 \mathrm{M}$ sucrose during centrifi tion (17); this method did not separate these large subcell particles in adult spleen or neonatal liver. The distinction am fractions is operational and is based on determinations of activities of some marker enzymes in liver; glutamate dehydrogenase (EC 1.4.1.4), cytochrome $c$ reductase (EC 1.6.99.2), and phosphoserine phosphatase (EC 3.1.3.3) were measured by established methods in the mitochondrial (14), microsomal (38), and soluble fractions (24), respectively. Routinely, thymidine kinase activities were measured in the cytosol and in the Triton-treated total particle preparations.

Thymidine kinase assays were based on the procedure described by Machovich and Greengard (30) except that the final concentation of thymidine was $0.04 \mathrm{mM}$ with a final specific activity of $5 \mu \mathrm{Ci} / \mu$ mole $\left(\left[{ }^{14} \mathrm{C}\right] 2\right.$-thymidine; New England Nuclear Corp., Boston, MA). After incubating the reaction mixtures (in total volumes of $0.5 \mathrm{ml}$ ) for $20 \mathrm{~min}$ at $37^{\circ} \mathrm{C}, 50 \mu \mathrm{l}$ were pipetted onto Whatman aminoethyl cellulose discs (DE81; Whatman Co., Clifton, $\mathrm{NJ}$ ). Nonphosphorylated thymidine was eluted by stirring the discs in 500 to $1000 \mathrm{ml}$ cold $1.0 \mathrm{mM}$ ammonium formate for 15 min followed by successive 5-min washes of water and $95 \%$ ethanol. The discs were counted in $10.0 \mathrm{ml}$ Aquasol (New England Nuclear Corp.) in a Packard Tri-Carb scintillation counter at $90 \%$ efficiency. Values for blanks, reaction mixtures without incubation or without ATP, were subtracted from the experimental samples.
The assay was linear with enzyme concentration and incubation time for $30 \mathrm{~min}$. Enzyme activities are expressed as $\mathrm{m} \mu$ (nmoles/ min) per $g$ tissue.

All reagents were obtained from Boehringer Mannheim Corp. (Indianapolis, IN), Sigma Biochemical Co. (St. Louis, M '), and Calbiochem (La Jolla, CA). Only reagent grade chemicals were used.

\section{RESULTS}

In adult rat liver, the total thymidine kinase actiyity is low, and its subcellular localization has been thought to be almost entirely cytosolic $(21,30)$. Careful subcellular fractionation of hepatic thymidine kinase revealed that in the adult rat, approximately on half of the low total activity was in the cytosol when the tissue

1: : jmogenized in $0.25 \mathrm{M}$ sucrose or $0.15 \mathrm{M} \mathrm{KCl}$ (Table 1), but nearly $50 \%$ was associated with the particles. However, liver from neonatal rats (as from fetal humans) contained virtually no particulate thymidine kinase. No enzyme activity was associated with microsomes. Other adult tissues (e.g., lung, thymus, kidney, and small intestine) had no appreciable activity in the particles. The low levels of adult soluble thymidine kinase have, in all tissues measured by us (19), been in sharp contrast to the enzyme activities in the homologous fetal tissues. Phosphatases, associated with particles or membrane fractions released during homogenization, may in part account for the low thymidine kinase activities in particles of adult rat tissues. However, some preliminary observations by us (15) indicate that treatment of particles with Triton X-100 (see "Materials and Methods") prevents the hydrolysis of thymidine monophosphate. Inasmuch as virtually no phosphatase activities that hydrolyze thymidine monophosphate in the presence of high ( $5 \mathrm{mM}$ ) concentrations of ATP can be detected in the cytosol (15), the low soluble thymidine kinase activities in adult tissues are unlikely to be artifacts of concurrent product hydrolyses.

The prenatal decreases in thymidine kinase activities in rat liver are well documented $(30,36)$. They have been associated with the diminished number of erythropoietic cells (30) and the hormonal changes occurring in the late fetus (11). The rapid transient hepatic accumulation of thymidine kinase after birth (Fig. 1) has not been described in detail (although it is suggested in Ref. 30, Fig. 3). Thymidine kinase activities in rat liver between 1 and 3 days postpartum were as high in the 19-day-old fetus; this could not be attributed to erythropoietic cells because the postnatal rat liver is no longer a blood-generating organ (11). Additional peaks in hepatic thymidine kinase activity appeared to coincide with increased and novel DNA synthesis preceding the times of new enzyme formation in liver (e.g., in late suckling rats and weanlings).

In the small intestine (Fig. 2), the major decrease in thymidine kinase activity occurred immediately postpartum (but not before

Table 1. Intracellular distribution of thymidine kinase in rat tissues

\begin{tabular}{|c|c|c|c|c|c|c|c|}
\hline & \multicolumn{2}{|c|}{$\begin{array}{c}\text { Enzyme activities }(\mathrm{m} \mu / \mathrm{g}) \text { in } 0.15 \\
\mathrm{M} \mathrm{KCl} \text { preparations }\end{array}$} & \multicolumn{5}{|c|}{$\%$ of total activity in fractions prepared in $0.25 \mathrm{M}$ sucrose } \\
\hline & Particles & Cytosol & Nuclei & Mitochondria & Microsomes & Cytosol & $\begin{array}{l}\text { Recovery of activ- } \\
\text { ity in } \mathrm{KCl} \text { prepa- } \\
\text { rations }\end{array}$ \\
\hline \multicolumn{8}{|l|}{ Liver } \\
\hline Adult (2) & 0.40 & 0.38 & 22 & 28 & 1 & 49 & 92 \\
\hline 2 day old (2) & 0.47 & 19.2 & 5 & 2 & 0 & 93 & 47 \\
\hline Spleen (adult) & 0.72 & 3.3 & & & 5 & 58 & 49 \\
\hline
\end{tabular}

${ }^{1}$ Fresh rat tissues were homogenized in 9 volumes of $0.15 \mathrm{M} \mathrm{KCl}$ and centrifuged for $30 \mathrm{~min}$ at $100,000 \times \mathrm{g}$ (columns 1 and 2 ). Tissue aliquots were also homogenized in 9 volumes of $0.25 \mathrm{M}$ sucrose and fractionated as described in Ref. 17. Overlaying $0.5 \mathrm{M}$ sucrose with the homogenates from adult spleen or 2-day-old liver did not result in a separation of layers; centrifugation at $280 \times g$ gave no discrete pellet. The overlaying step was therefore omitted, and nuclei were separated by simple centrifugation at $300 \times \mathrm{g}$ from $0.25 \mathrm{M}$ sucrose homogenates. The resulting pellet was washed once. Microscopically, essentially only nuclei could be identified (2-day-old liver). 
birth), and renewed accumulation was delayed until the fourth postnatal wk. This late rise was not causally related to the dietary change at weaning because rats already supplement their milk diets with adult solid food during the third wk and 24- to 30-day old unweaned rats exhibited thymidine kinase activities at least as high as those of their weaned littermates (Fig. 2). Activities in the colon were halved between the sixth postnatal day and adulthood, but the changes were gradual and not associated with any known physiological or maturational event. In the rat lung (Fig. 3), the steepest decline in thymidine kinase activities had already passed at 2 days before birth. The constancy of the enzyme activity in lung around the time of birth (see also Table 2) suggests that the stimuli which normally raise (e.g., liver) or lower (e.g., small intestine) thymidine kinase activities in those tissues around parturition do not trigger such changes in the lung.

The dramatic developmental changes in hepatic and intestinal thymidine kinase activities at the time of birth could be the culmination of normal, sequential prenatal developmental changes, or they could be triggered by the event of birth per se. In the first case, prematurely delivered fetuses would not exhibit the

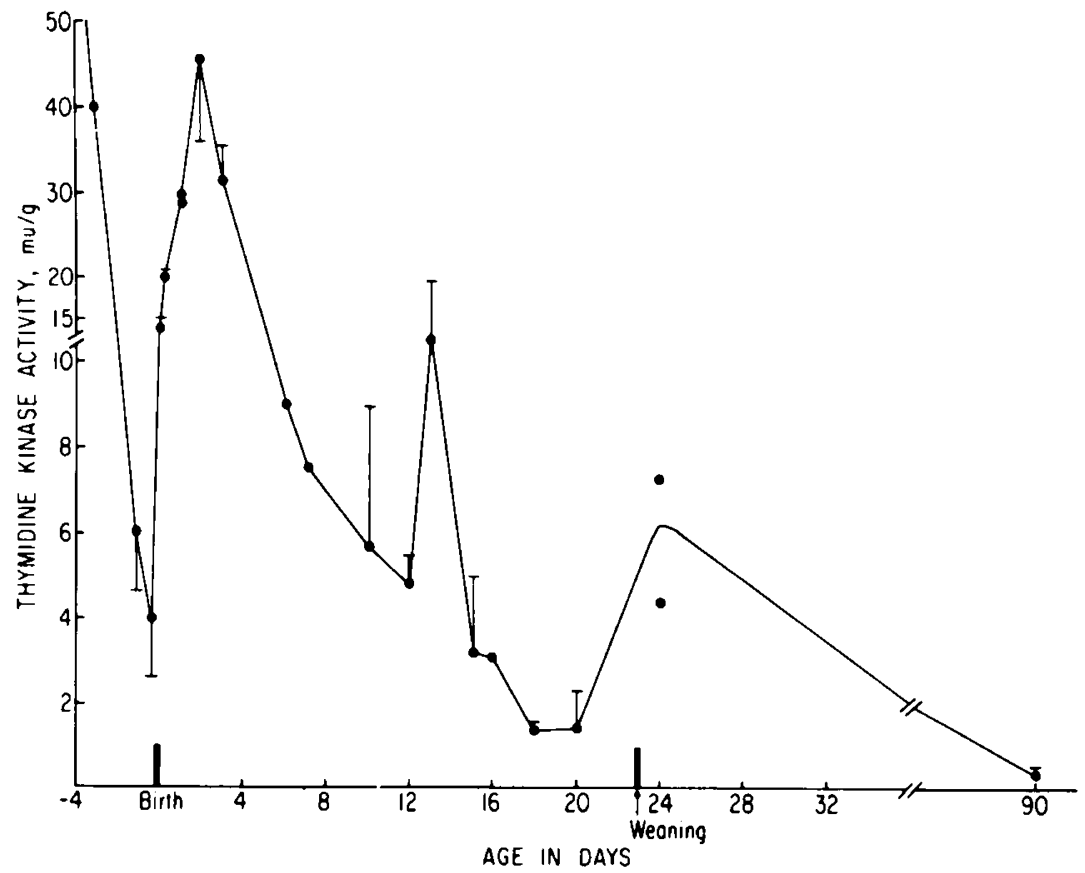

Fig. 1. The development formation of thymidine kinase in rat liver. Soluble thymidine kinase activity was determined in pools of livers from one to four litters (fetal points) and in individual livers after birth. Points show means (bars, = 1 S.D.) of values for three or more animals or single determinations. N.B., change in scale in ordinate between 10 and $15 \mathrm{~m} \mu / \mathrm{g}$.

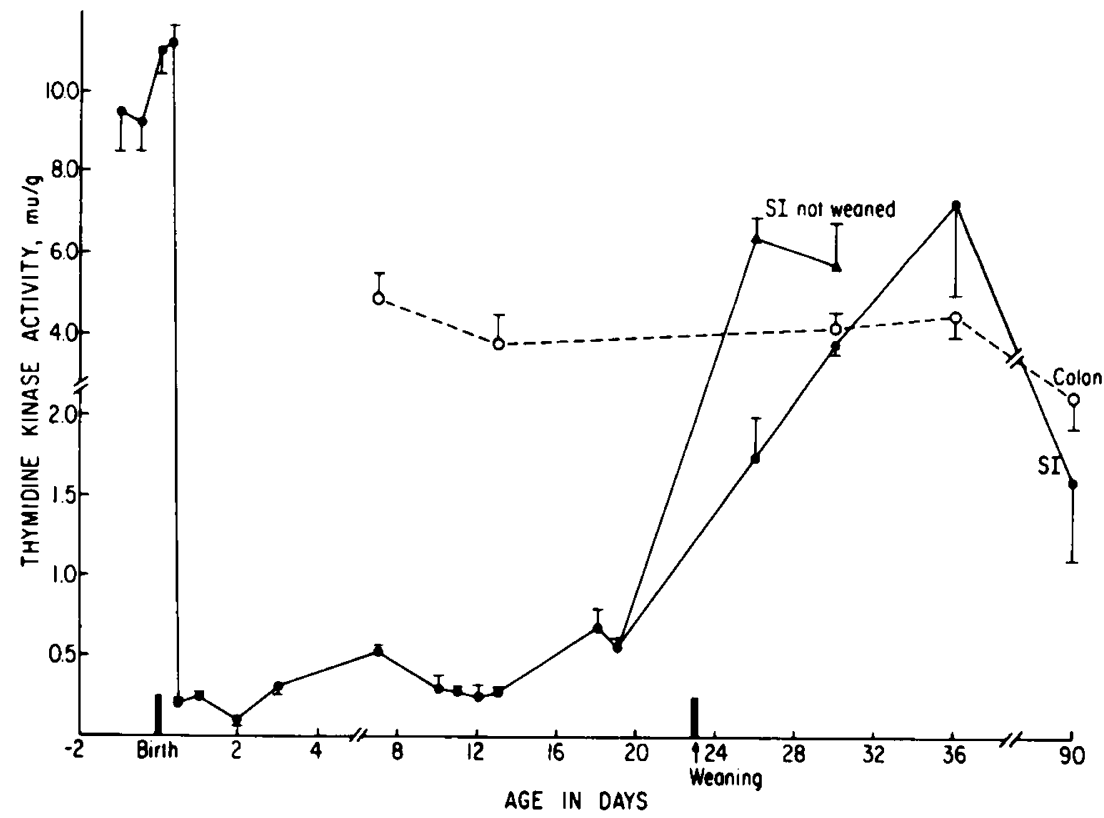

Fig. 2. Thymidine kinase in small intestine and colon of the rat during development. Soluble thymidine kinase activities were measured in pools of fetal small intestine, in small intestine of individual postnatal rats (15 days), or in jejunum of individual older rats ( - -). Rats are normally weaned at 23 days $(\Theta)$; some littermates were kept with their dams beyond that age $(\Delta)$. Activities in colon $(---, O)$ were measured in three rats at each age. Points are means of results from three or more litters or animals (bars, 1 S.D.). 


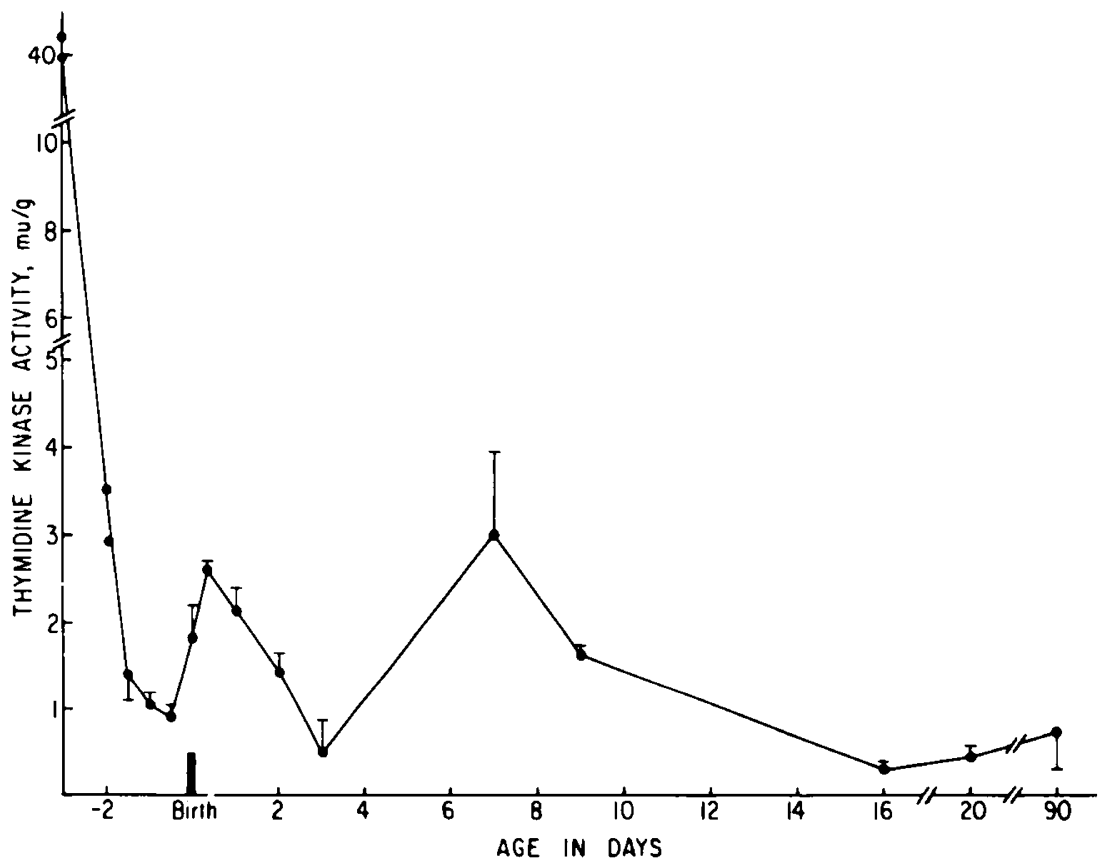

Fig. 3. Changes in thymidine kinase in rat lung with age. Soluble thymidine kinase activities were measured in pooled fetal lungs from one to four litters or in lungs of individual postnatal rats. Points are means of results (bars, 1 S.D.) from three or more litters or animals or from a pool of a single litter (no S.D.). N.B., changes in scale on ordinate between 5.0 and 6.0 and between 10 and $40 \mathrm{m \mu} / \mathrm{g}$.

same changes as rats born at full term; if extrauterinization itself contributed to the changes, they would be displayed equally in rats delivered prematurely or at term. Table 2 shows that the process of birth itself, not the sequence of events immediately preceding it (e.g., hormonal modifications in the dam or fetus, loss of hematopoiesis in liver, etc.), led to the altered thymidine kinase activities. Although the absolute enzyme activities ( $\mathrm{nm} / \mathrm{g}$ tissue) in livers and lungs of prematurely delivered rats (20th to 21 st days of gestation) were higher than those in animals killed at an older conceptual age (i.e., normal delivery at 22 days), the relative hepatic changes in the first $24 \mathrm{hr}$ (e.g., 66 and 199\% enzyme increases over the levels at birth in prematurely and normally born rats, respectively) were similar. Enzyme levels in lung were constant (and low) after premature or normal delivery. As expected, activities in the small intestine were equally high at the early and normal delivery times, and thymidine kinase levels dropped to similarly low values $24 \mathrm{hr}$ later under both conditions of delivery. Thus, in all three tissues the time after the event of birth, not the conceptual age at birth, determined the enzyme levels.

Among the likely factors affecting thymidine kinase activities around the time of extrauterinization are changes in the levels of fetal hormones and the abrupt deprivation of the newborn of maternal hormones. We therefore began to test the responsiveness of thymidine kinase activities in liver, lung, and small intestine of fetal and postnatal rats to an injection of thyroxine or cortisol. An injection of $3 \mu \mathrm{g}$ thyroxine even on the 20th day of gestation maintained the hepatic thymidine kinase activities at levels $50 \%$ higher than in the untreated fetal littermates (Table 3 ). Thyroxine prevented the prenatal decline in pulmonary thymidine kinase only in the younger fetuses and had no significant effects on the intestinal enzyme. After birth, thyroxine was ineffective in all three tissues. Cortisol partially decreased hepatic thymidine kinase activities in fetuses or in pups younger than a wk but virtually erased it in older sucklings. Pulmonary thymidine kinase in fetal and young postnatal rats was nearly eliminated after an injection of cortisol; the intestinal enzyme was diminished only slightly by the cortisol treatment in neonatal rats ( 30 to $40 \%$ decreases), but the hormone was ineffective in altering thymidine kinase activities in small intestines of rats older than 11 days.

Some of the other intestinal enzymes that undergo substantial
Table 2. Thymidine kinase changes around the time of delivery ${ }^{1}$

\begin{tabular}{|c|c|c|c|}
\hline & \multicolumn{3}{|c|}{$\begin{array}{l}\text { Time after delivery (thymidine kinase activity: } \\
\qquad \mathrm{m} \mu / \mathrm{g})\end{array}$} \\
\hline & $15 \mathrm{~min}$ & $4 \mathrm{hr}$ & $24 \mathrm{hr}$ \\
\hline \multicolumn{4}{|l|}{ Liver } \\
\hline $\begin{array}{r}\text { Premature } \\
\text { delivery }\end{array}$ & $20.6 \pm 13.6^{2}(3)^{3}$ & $25.4 \pm 9.7$ & 34.2 \\
\hline Normal birth & $14.0 \pm 1.3$ & $20.4 \pm 0.5$ & $29.1 \pm 1.6$ \\
\hline \multicolumn{4}{|l|}{ Lung } \\
\hline $\begin{array}{l}\text { Premature } \\
\text { delivery }\end{array}$ & $8.7 \pm 6.77$ & $8.23 \pm 7.58$ & \\
\hline Normal birth & $1.86 \pm 0.4$ & $2.6 \pm 0.09$ & $2.15 \pm 0.25(3)$ \\
\hline \multicolumn{4}{|l|}{ Small intestine } \\
\hline $\begin{array}{r}\text { Premature } \\
\text { delivery }\end{array}$ & $11.14 \pm 8.9$ & $9.73 \pm 11.24$ & $0.18 \pm 0.05(3)$ \\
\hline Normal birth & $10.95 \pm 0.95$ & $11.1 \pm 0.5$ & $0.25 \pm 0.03$ \\
\hline
\end{tabular}

${ }^{1}$ Fetuses of four time-mated CDF females were delivered by Caesarian section 10 to $24 \mathrm{hr}$ before the expected normal parturition time. Some fetuses were kept on $0.9 \% \mathrm{NaCl}$ solution-soaked gauze sheets in a $37^{\circ} \mathrm{C}$ incubator in which vessels of water were also contributing to the humidity for $4 \mathrm{hr}$. Some of these rats were then killed while the remainders of the litters were transferred for $18 \mathrm{hr}$ to foster mothers on the second day of lactation. Pups from litters born naturally were removed $15 \mathrm{~min}$ after birth and either killed ( $T=15 \mathrm{~min}$ ) or stored under the same conditions as the prematurely delivered ones. Tissues from littermates were pooled for assays.

${ }^{2}$ Mean \pm S.D.

${ }^{3}$ Numbers in parentheses, number of specimens tested.

impermanent neonatal declines [e.g., uridine kinase (EC 2.7.1.48) (18) and pyrroline-5-carboxylate reductase (EC 1.5.1.2) (20)] are re-elicited during this quiescent period by an injection of cortisol or an 18-hr period of starvation $(18,20)$. Neither treatment evoked changed thymidine kinase levels in liver or intestine of the same rats. None of the tissues from young control or hormone-treated rats had thymidine kinase activity associated with particles. 
Curves of the postnatal development of thymidine kinase in rat spleen, thymus, kidney, and brain have been published $(10,11$, $19,30)$. The high enzyme activity in the thymus did not coincide with the period of lowest adrenal-pituitary activity (28), even though the involution of the thymus, after injections of cortisol in adults, was accompanied by decreased thymidine kinase activities (10), the normal developmental resumption of adrenal function in young postnatal rats did not reduce the weight of the thymus or its thymidine kinase activity at the age of 10 to 12 days. The major relative loss in enzyme activity and weight occurred after the 14th day (19).

In fetal human liver and lung (Table 4), as in the rat tissues, soluble thymidine kinase activities were significantly higher than those in adults. In liver, the activities in the first and second trimesters were essentially constant, but a substantial decrease occurred some time between the 20th wk of gestation and the first postnatal day. (Although our samples of human liver reveal no changes in soluble thymidine kinase in the first neonatal wk, these observations are based on neonates who were obviously not developing normally; their causes of death included ornithine transcarbamylase deficiency associated with ammonia intoxication, adrenal insufficiency, and respiratory distress syndrome.) Particulate thymidine kinase was the predominant species in adult human liver (68\% of total) and lung (59\% of total activity) $(8,9$, 21). This form of thymidine kinase, virtually absent from fetal liver, equalled $20 \%$ (first trimester) and $40 \%$ (second trimester) of the total thymidine kinase activity in fetal human lung. Like liver and lung, fetal colon contained substantially higher concentrations of thymidine kinase than the adult colon (Table 4); as in the other human tissues, the particulate form of the enzyme was the predominant species in the adult (but not the fetal) colon. The few values we have accumulated for human small intestine contained no more soluble (but slightly higher particulate) thymidine kinase activities than the adult.

\section{DISCUSSION}

The proportionality between thymidine kinase concentrations and growth rate in normal development $(1,3,33-36)$, regenerating liver $(22,31)$, and rat tumors $(6,30,33)$ is well documented. The present comparisons between thymidine kinase activities in fetal and adult liver, lung, small intestine, and colon of rat and man are in accordance with previous observations $(33,35,36)$. Fetal tissues (in man and rat) contained higher concentrations of soluble thymidine kinase than did the adult. The persistence and magnitude of the fetal thymidine kinase concentrations varied from one tissue to another and was independent of the ultimate mean adult concentration. For instance, rat liver and lung, both with low adult concentrations $(<0.5 \mathrm{~m} \mu / \mathrm{g})$, exhibited prenatal activities of over $40 \mathrm{~m} \mu / \mathrm{g}$, whereas in small intestine (with $1.6 \mathrm{~m} \mu / \mathrm{g}$ adult jejunum) the highest concentration was only $10 \mathrm{~m} \mu / \mathrm{g}$.

The present observations extend previous findings on the developmental formation of the enzyme in rat tissues $(7,11,30)$ and generally agree with the recent observations of a neonatal increase

Table 3. Effects of thyroxine or cortisol on thymidine kinase in rat tissues ${ }^{1}$

\begin{tabular}{|c|c|c|c|c|c|c|c|c|c|}
\hline \multirow[b]{3}{*}{ Age } & \multicolumn{3}{|c|}{ Liver } & \multicolumn{3}{|c|}{ Lung } & \multicolumn{3}{|c|}{ Small intestine } \\
\hline & \multirow{2}{*}{$\begin{array}{l}\text { Control } \\
(\mathrm{m} \mu / \mathrm{g})\end{array}$} & \multicolumn{2}{|c|}{$\begin{array}{l}\% \text { of activity after injection } \\
\text { with: }\end{array}$} & \multirow{2}{*}{$\begin{array}{l}\text { Control } \\
(\mathrm{m} \mu / \mathrm{g})\end{array}$} & \multicolumn{2}{|c|}{$\begin{array}{l}\% \text { of activity after injection } \\
\text { with: }\end{array}$} & \multirow{2}{*}{$\begin{array}{l}\text { Control } \\
(\mathrm{m} \mu / \mathrm{g})\end{array}$} & \multicolumn{2}{|c|}{$\begin{array}{c}\% \text { of activity after injection } \\
\text { with: }\end{array}$} \\
\hline & & Thyroxine & Cortisol & & Thyroxine & Cortisol & & Thyroxine & Cortisol \\
\hline$-11 / 2$ & $7.91 \pm 1.90^{2}$ & $165.0 \pm 30.0$ & 61.0 & $2.67 \pm 0.96$ & $157.0 \pm 2.0$ & $13.0 \pm 14.0$ & $9.68 \pm 1.20$ & $112.0 \pm 4.0$ & \\
\hline$-1 / 2$ & $5.31 \pm 1.00$ & $148.0 \pm 30.0$ & & 0.93 & 88.0 & & $9.20 \pm 0.78$ & $83.0 \pm 3.0$ & \\
\hline $\begin{array}{l}+1 \\
+2\end{array}$ & $\begin{array}{l}15.0 \\
45.3 \pm 9.7\end{array}$ & $106.0 \pm 8.0$ & 60.0 & $2.30 \pm 0.35$ & & $13.0 \pm 2.0$ & $0.19 \pm 0.06$ & 81.4 & $72.0 \pm 16.0$ \\
\hline+4 & $7.12 \pm 0.57$ & & $19.0 \pm 1.0$ & 8.42 & & 0 & & & \\
\hline+7 & $7.50 \pm 2.35$ & & $10.0 \pm 4.0$ & $3.30 \pm 0.88$ & & $6.0 \pm 12.0$ & $0.55 \pm 0.18$ & 69.0 & $60.0 \pm 5.0$ \\
\hline+11 & $5.7 \pm 5.2$ & & $2.0 \pm 0.3$ & & & & $0.28 \pm 0.06$ & & $114.0 \pm 10.0$ \\
\hline+16 & $3.1 \pm 1.4$ & & $3.0 \pm 3.0$ & $0.30 \pm 0.05$ & & $14.0 \pm 3.0$ & & & \\
\hline+20 & $1.43 \pm 0.89$ & & $9.4 \pm 4.0$ & $0.44 \pm 0.17$ & & $55.0 \pm 14.0$ & $0.52 \pm 0.07$ & & $92.0 \pm 19.0$ \\
\hline+90 & $0.4 \pm 0.3$ & & & $0.75 \pm 0.40$ & & & $1.63 \pm 0.58$ & & \\
\hline
\end{tabular}

${ }^{1}$ Animals were given injections of hydrocortisone acetate $(250 \mu \mathrm{g} / 10 \mathrm{~g}$ body weight) or thyroxine (3 $\mu \mathrm{g}$ per fetus or $20 \mu \mathrm{g} / 10 \mathrm{~g}$ body weight postnatally) $18 \mathrm{hr}$ before assay. When S.D.'s are given, three to six animals or tissue pools from three litters were assayed.

${ }^{2}$ Mean \pm S.D.

Table 4. Thymidine kinase activities in fetal and adult human tissues (thymidine kinase activities, $\mathrm{m} \mu / \mathrm{g}$ )

\begin{tabular}{|c|c|c|c|c|c|c|c|c|c|}
\hline \multirow[b]{2}{*}{ Age } & \multicolumn{3}{|c|}{ Liver } & \multicolumn{2}{|c|}{ Lung } & \multicolumn{2}{|c|}{ Colon } & \multicolumn{2}{|c|}{ Small intestine } \\
\hline & Soluble & & Particulate & Soluble & Particulate & Soluble & Particulate & Soluble & Particulate \\
\hline \multicolumn{10}{|l|}{ Fetals $^{1}$} \\
\hline$<16$ wk & $14.83 \pm 4.87^{2}$ & $(4)^{3}$ & $0.30 \pm 0.40$ & $2.39 \pm 1.09(3)$ & $0.30 \pm 0.30(3)$ & & & & \\
\hline$>16 \mathrm{wk}$ & $12.53 \pm 7.67$ & (12) & $1.33 \pm 1.39(6)$ & $0.68 \pm 0.36(6)$ & $0.81 \pm 0.23(4)$ & $1.65 \pm 0.33(4)$ & $0.58 \pm 0.82(3)$ & $0.86 \pm 0.17(2)$ & $1.61 \pm 1.01(2)$ \\
\hline \multicolumn{10}{|l|}{ Neonatal } \\
\hline$<1$ day $^{4}$ & $2.14 \pm 1.00$ & (3) & $1.01 \pm 0.92$ & & & & & & \\
\hline 3-6 days & $0.85 \pm 0.18$ & (3) & $2.31 \pm 0.68$ & $0.17 \pm 0.11(3)$ & $0.52 \pm 0.26(3)$ & & & & \\
\hline Adult $^{5}$ & $1.34 \pm 0.44$ & (12) & $2.86 \pm 1.35(8)$ & $0.55 \pm 0.33(6)$ & $0.79 \pm 0.50(6)$ & $0.61 \pm 0.26(9)$ & $0.75 \pm 0.37(9)$ & 1.10 & 0.74 \\
\hline
\end{tabular}

' Fetal ages were estimated by crown-rump length, according to Bartolucci (2).

${ }^{2}$ Mean \pm S.D.

${ }^{3}$ Numbers in parentheses, number of specimens.

${ }^{4}$ Premature births.

${ }^{5}$ Adult livers were histologically normal. 
of thymidine kinase in mouse cerebellum (3). In liver, the normal decrease in enzyme activities before birth (30) (Fig. 1), was followed immediately by a significant rise in thymidine kinase activity which was not accompanied by an increase in the number or volume of hematopoietic cells (11). The high hepatic activities in the early postnatal period represent a considerable concentration of the enzyme in the cytosol because at that time the amount of cytoplasm per hepatocyte is still small ( $30 \%$ of that in the adult) (16). The elevated neonatal hepatic thymidine kinase activity coincided with that of uridine kinase (18) and was independent of the conceptual age of the rat (Table 2); it occurred equally in prematurely and normally delivered fetuses. Hepatic thymidine kinase appeared to be regulated sequentially by thyroxine (which lost its capacity to delay the normal drop after birth) and cortisol which partially accelerated the normal decrease in fetal liver and arrested thymidine kinase activity almost completely after birth (Table 3; Ref. 11).

The developmental changes in thymidine kinase activities in rat intestine and lung resembled those of liver in general pattern but differed in several details, such as the precise timing of the maturational changes, their magnitude, and their regulation by thyroxine or cortisol. The high levels of the intestinal enzyme in the fetus became minimal relatively late in development (more than $4 \mathrm{hr}$ after delivery) and independently of the conceptual age Active intestinal thymidine kinase synthesis was not resumed until the fourth postnatal wk when activities became almost as high as in the late fetus in both weaned and unweaned rats. Thyroxine did not influence the accumulation or decrease of the enzyme in small intestine before or after birth, and cortisol was only a partial regulator for the intestinal enzyme. Although the normal maturational pattern of intestinal thymidine kinase resembled that of uridine kinase (18), intestinal thymidine kinase did not accumulate in response to an injection of cortisol or starvation in neonates. Thymidine kinase in fetal lung decreased earlier than the enzyme in either liver or small intestine, and the postnatal increase (smaller than in liver) also preceded that of liver ( $c f$. Figs. 1 and 3). The decline in fetal pulmonary thymidine kinase was not slowed by thyroxine; cortisol almost eliminated both fetal and neonatal activities in rat lungs. In contrast to liver, where cortisol regulated the enzyme activity least effectively in the fetus, cortisol-control of the lung enzyme diminished with increasing age.

The event of birth seemed to trigger an immediate appearance of hepatic thymidine kinase (Fig. 1). Fetuses killed immediately after delivery on the 21 st day of gestation had significantly lower activities than did pups delivered at the same time but kept alive for less than $15 \mathrm{~min}$. We have no explanation for this phenomenon, but it is well known that premature delivery can induce precocious rises in several gluconeogenic and amino acid metabolizing enzymes in man and rodents $(4,29,37,39)$.

One of the contrasts between thymidine kinase in man and rat is in the subcellular distribution of the enzyme in the respective tissues. Multiple forms of thymidine kinase have been reported for rat tumors and regenerating livers (31) but not for normal rat tissues $(12,33,36)$; in man, soluble and particulate forms with different chemical properties have been described for normal tissue also $(22,26,27,36)$

The distribution of the two enzymic forms varies with age in human liver $(8,21)$ and lung $(9)$. Although soluble thymidine kinase in liver of fetuses between 10 and $22 \mathrm{wk}$ underwent no quantitative developmental changes, the particulate form of the enzyme, almost undetectable in the first two trimesters, reached significant levels soon thereafter. The precipitous drop in soluble hepatic thymidine kinase after midgestation was not mirrored in the particulate form of the enzyme which continued to rise substantially so that in the adult liver, nearly $70 \%$ of the total activity was associated with particles. As in the rat lung, the decline in soluble thymidine kinase occurred earlier in human fetal lungs than in the liver; adult levels of the particulate enzyme were reached in lungs of second trimester fetuses. The morbidity of the neonates whose postmortem tissues we obtained makes uncertain even the results of the activities of enzymes not directly involved in the pathology of the infants. The neonatal tissues differed from those of the fetus in the longer time that elapsed between death and tissue preparation; they differed from those of the adult in being autopsy rather than fresh surgical material. The thymidine kinase activities in neonatal tissues are therefore not strictly comparable to those of fetuses or adults and should be viewed (skeptically) as minimal levels.

Since fetal and neonatal rat tissues were essentially devoid of particulate thymidine kinase, the effect of cortisol could only be determined for the cytosolic enzyme. Neonatal rat, in this case, fails to provide a model system for human enzyme development. It would have been of particular interest to assess the effects of cortisol on the developmental changes in particulate lung thymidine kinase in view of the clinical use of cortisol for the enhancement of surfactant synthesis in premature births (5). In human colon, the soluble and particulate forms of thymidine kinase also had opposite developmental formations, with decreases in the soluble and increases in the particulate forms occurring concurrently. As in the rat (Fig. 2), in man the ontogenic changes were less extreme in intestine than in liver or lung.

Recent observations by us (15) have indicated that particles of adult rat spleen and to a smaller extent, thymus (tissues with high soluble thymidine kinase activities), hydrolyze thymidine nucleotides specifically. Particles from other rat tissues did not catalyze this reaction but contained phosphatases that hydrolyzed dinitrophenylphosphate $(14 \mathrm{mM})$. In human liver, particles did not hydrolyze thymidine monophosphate, but cytosol did slightly. The soluble thymidine kinase activities detected in human liver cytosol may therefore be only apparent activities. The subcellular translocalization of the enzyme activities metabolizing thymidine nucleotides (e.g., thymidine kinase and phosphatase) in human and rat tissues may account for the relatively high particulate kinase activities in adult human tissues when compared to those in the rat.

\section{CONCLUSION}

During ontogeny, soluble thymidine kinase in rat liver, lung, and small intestine exhibited high fetal activities in all three tissues. The time of the normal decline of thymidine kinase activities varied with the tissues as did the postnatal re-emergence which occurred at 1 to 2 days after birth in lung and liver and not until the fourth wk in small intestine. Although thymidine kinase activities in liver and lung (but not intestine) were reduced by cortisol, an injection of thyroxine into fetuses (but not into neonates) maintained only hepatic thymidine kinase activity at a level higher than that of untreated littermates. The developmental changes in thymidine kinase activities in liver (increase) and small intestine (decrease) immediately after birth were not dependent on the conceptual age but occurred as consequences of birth per se.

Thymidine kinase in normal adult human tissues appeared predominantly particle bound. Fetal human liver, lung, and colon were essentially devoid of the particulate enzyme which accumulated during or after the second trimester; the soluble enzyme of liver remained at a constant concentration between the 10th to the 22nd wk of gestation whereas that of lung began its decline toward adult levels after the 16th wk. As in the rat, soluble thymidine kinase in adult liver, lung, and intestine of man was significantly lower than in the fetal homologous tissues.

\section{REFERENCES AND NOTES}

1. Adler, R., and McAuslan, B. R.: Expression of thymidine kinase variants as a function of the replicative state of cells. Cell, 2: 113 (1974).

2. Bartolucci, L. Biparietal diameter of the skull and fetal weight in the second trimester: An allometric relationship. Am. J. Obstet. Gynec., 122: 439 (1975).

3. Caron. P. C., and Unsworth, B. R.: Alteration of the activity and molecular form of thymidine kinase during development and aging in the mouse cerebellum. Mech. Aging Dev., 8: 181 (1978).

4. Del Valle, J. A., and Greengard. O.: Phenylalanine hydroxylase and tyrosine aminotransferase in human fetal and adult liver. Pediatr. Res., 11: 2 (1977).

5. Farrell, P. M.. and Avery M. E.: Hyaline membrane disease (state of the art). Am. Rev. Respir. Dis.. 111: 657 (1975). 
6. Garland, M. R., Ng. T., and Richards, J. F.: Hormonal effects of thymidine kinase activity in normal rat adrenal and in hormone-dependent adrenal carcinoma. Cancer Res., 31: 1348 (1971).

7. Greengard, O.: Steroids and the maturation of rat tissues. J. Steroid Biochem., 6 : 639 (1975).

8. Greengard, O.: Enzymic differentiation of human liver: comparison with the rat model. Pediatr. Res., II: 669 (1977).

9. Greengard, O., and Herzfeld, A.: The undifferentiated enzymic composition of human fetal lung and pulmonary tumors. Cancer Res., 37: 884 (1977).

10. Greengard, $O$., and Lempert, $N$.: Effects of tumor-bearing. phenylhydrazine and cortisone on thymidine kinase and other enzymes in rat hematopoietic organs. Enzyme, 14: 229 (1972/73).

11. Greengard, O., and Machovich, R.: Hydrocortisone regulation of thymidine kinase in thymus involution and hematopoietic tissues. Biochim. Biophys. Acta, 286: 382 (1972).

12. Hashimoto, T., Shiosaka, T., Toide, H., Okuda, H., and Fujii, S.: Thymidine kinases from normal and tumor tissues. Gann. 60: 41 (1969).

13. Herbst, J. J., Fortin-Magana, R., and Sunshine, P.: Relationship of pyrimidine biosynthetic enzymes to cellular proliferation in rat intestine during development. Gastroenterology, 59: 240 (1970).

14. Herzfeld, A.: The distribution of glutamate dehydrogenase in rat tissues. Enzyme. 13: 246 (1972)

15. Herzfeld, A. (unpublished observations)

16. Herzfeld, A., Federman, M., and Greengard, O.: Subcellular morphometric and biochemical analyses of developing rat hepatocytes. J. Cell Biol., 57: 475 (1973).

17. Herzfeld, A., and Greengard, O.: Aspartate aminotransferase in rat tissues: changes with growth and hormones. Biochim. Biophys. Acta, 237: 88 (1971).

18. Herzfeld, A., and Raper, S. M.: Uridine kinase activities in developing, adult and neoplastic rat tissues. Biochem. J., 182: 771 (1979)

19. Herzfeld, A., and Raper, S. M.: The relative activities of thymidylate synthetase and thymidine kinase in rat tissues. Cancer Res., 40: 744 (1980).

20. Herzfeld, A., and Raper, S. M.: Effects of cortisol or starvation on the developmental formation of enzymes in small intestine and liver of the rat. J. Dev. Physiol., I: 315 (1979).

21. Herzfeld, A., Rosenoer, V. M., and Raper, S. M.: Glutamate dehydrogenase alanine aminotransferase, thymidine kinase, and arginase in fetal and adult human and rat liver. Pediatr. Res., 10: 960 (1976).

22. Hopkins, H. A., Campbell, H. A., Barbiroli, B., and Potter, V. R.: Thymidine kinase and deoxyribonucleic acid metabolism in growing and regenerating livers from rats on controlled feeding schedules. Biochem. J., 136: 955 (1973).

23. Kit, S., Leung, W.-C., and Trkula, D.: Properties of mitochondrial thymidine kinases of parental and enzyme-deficient Hela cells. Arch. Biochem. Biophys. 158: 503 (1973).

24. Knox, W. E., Herzfeld, A., and Hudson, J.: Phosphoserine phosphatase distribution in normal and neoplastic rat tissues. Arch. Biochem. Biophys., 132: 397 (1969).

25. Knox, W. E., and Lister-Rosenoer, L. M.: Timing of gestation in rats by fetal and maternal weights. Growth, 42: 43 (1978).

26. Lee. L. S., and Cheng. Y. C.: Human deoxythymidine kinase. I. Purification and general properties of the cytoplasmic and mitochondrial isoenzymes derived from blast cells of acute myelocytic leukemia. J. Biol. Chem., 25l: 2600 (1976). 27. Lee, L. S., and Cheng, Y. C.: Human deoxythymidine kinase. II. Substrate specificity and kinetic behavior of the cytoplasmic and mitochondrial isoenzymes derived from blast cells of acute myelocytic leukemia. Biochemistry, 15: 3686 (1976).

28. Levine, S., and Mullins, R. F.: Hormonal influences on brain organization in infant rats. Science (Wash. D.C.), 152: 1585 (1966).

29. Litwack. G., and Nemeth, A. M.: Development of liver tyrosine aminotransferase activity in the rabbit, guinea pig and chicken. Arch. Biochem. Biophys., 109. 316 (1965).

30. Machovich, $R$., and Greengard, $O$.: Thymidine kinase in rat tissues during growth and differentiation. Biochim. Biophys. Acta, 286: 375 (1972).

31. Nawata, H., and Kamiya, T.: Two molecular forms of thymidine kinase in the cytosol of regenerating rat liver. J. Biochem., 78: 1215 (1975).

32. Nawata, H., Kato, K., and lbayashi, H.: Properties of thymidine kinase partially purified from human adrenal glands. Gann, 67: 561 (1976).

33. Ohashi, M., and Taguchi, T.: Two forms of thymidine kinase in normal and tumor tissues of animals. Cancer Res., 36: 2216 (1976).

34. Okuda. H., Arima, T., Hashimoto, T., and Fujii. S.: Multiple forms of deoxythimidine kinase in various tissues. Cancer Res., 32: 791 (1972).

35. Salser, J. S., and Balis, M. E.: Distribution and regulation of deoxythymidine kinase activity in differentiating cells of mammalian intestines. Cancer Res., 33: 1889 (1973).

36. Taylor, A. T., Stafford, M. A., and Jones, O. W.: Properties of thymidine kinase partially purified from human fetal and adult tissue. J. Biol. Chem., 247: 1930 (1972).

37. Vogel, W. H., Boehme, D. H., and Salerno, N. J.: Activities of tyrosine aminotransferase in various human tissues. J. Neurochem., 21: 705 (1973).

38. Williams, C. H., Jr., and Kamin, H.: Microsomal triphosphopyridine nucleotidecytochrome $c$ reductase of liver. J. Biol. Chem., 237: 587 (1962).

39. Yeung, D., and Oliver, I. T.: Development of gluconeogenesis in neonatal rat liver. Effect of premature delivery. Biochem. J., 105: 1229 (1967).

40. The protocols for the research on fetal and adult human tissues were approved by the Research Advisory Committee of the Boston Hospital for Women and the Committee on Clinical Investigation at the New England Deaconess Hospital, respectively.

41. This is article 672 from the Cancer Research Institute of the New England Deaconess Hospital.

42. The present address of Ira Gore is: Duke University School of Medicine, Durham NC (USA).

43. Requests for reprints should be addressed to: Dr. Annemarie Herzfeld, Cancer Research Institute, New England Deaconess Hospital, 194 Pilgrim Road. Boston, MA (USA)

44. This research was supported by Grant HD 12552, awarded by the National Institute of Child Health and Human Development, Department of Health Education, and Welfare, and Grant CA 22065, awarded by the National Cancer Institute, Division of Research Resources, Department of Health. Education, and Welfare.

45. Received for publication July 30, 1979.

46. Accepted for publication March 19. 1980. 